\title{
The Character of Kawit Carving as Identity in Regional Library
}

\author{
Evan Christian $^{1}$ Murni Rachmawati $^{2}$ \& Bambang Soemardiono ${ }^{3}$ \\ ${ }^{1}$ Postgraduate Student of Architecture Design \\ ${ }^{2-3}$ Department of Architecture, Sepuluh November Institute of Technology \\ Indonesia
}

\begin{abstract}
Because of the increasing globalization in various fields including fields architecture in Indonesia, this opportunity needs to be used to globalize local Indonesian architecture. The purpose of this paper is to produce a design that is capable of meeting every design and afford criteria shows the transformation process of kawit carving as the identity of the area on regional library in North Kalimantan. Besides that, they are able to apply theories identity and transformation in the design object so that the meaning and form of Kawit carvings can be seen as regional identities. Then for explain the character of kawit carvings which are used as identities in the North Kalimantan regional library. The results of the analysis and data collection explain the elements of kawit carving that make their identity strong are the circular shapes in the middle and arches on each side, besides the methods that can be used in the transformation process are extended, broken down and reduced to produce building shapes.
\end{abstract}

Key Words: Kawit Carving, Regional Identity, transformation.

\section{INTRODUCTION}

The character of kawit carving as an identity from North Kalimantan is applied in the design of the library, this is an opportunity to maintain the identity of North Kalimantan while demonstrating Indonesia's local identity in the field of architecture to be known globally. The identity aspect described in this journal is an aspect of the symbol of kawit carving from North Kalimantan which is a symbol of the unity and close relations between the people of North Kalimantan. These values that want to show globally as the identity of North Kalimantan.

\section{LITERATURE REVIEW}

\subsection{Kawit Carving}

Kawit carving is an ornament with a curved shape on its sides and a circle in the middle. Curved lines and circles take the basic motif of ferns or stylized nails in such a way that they don't resemble the original shape, Billa, 2017. The existence of curved ornaments and interconnected circles in the Dayak Kenyah community became a symbol of the endless descendants of the Dayak people who could unite the Dayak community. Circle ornaments symbolize each of the Dayak chiefs and sub-tribes in Kalimantan. The ornament of this curved line and circle teaches about brotherhood.

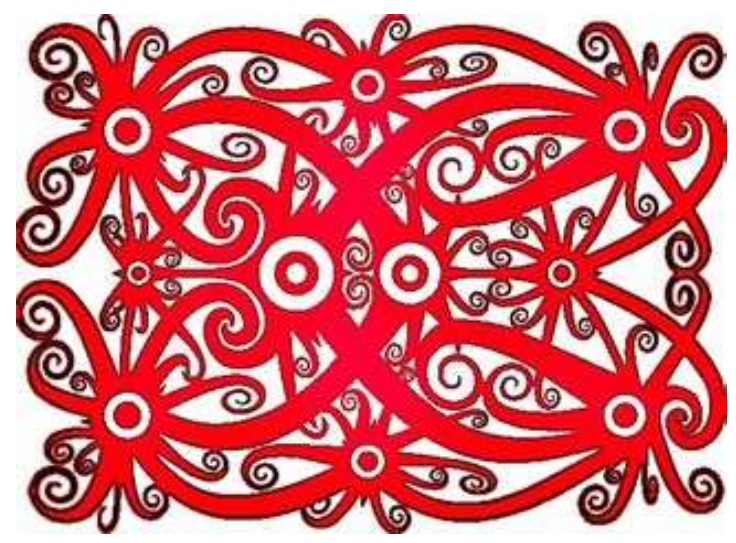

Fig.1 Kawit Carving 
To interpret this Kawit carving, it can be viewed in terms of semiotics which explains that a sign can be described through three levels of meaning, namely:

a) Definition of Denotation

The meaning manifested through the existence of curved and circular line ornaments is a symbol of the unity of all Dayak communities in Kalimantan as something that must be maintained. Curved lines are shaped like tendrils and ferns that grow in the forests of Borneo.

b) Meaning of connotation

The meaning to be conveyed through the ornament of curved lines and circles is as a symbol of all interconnected Dayak chiefs, intertwined with one another with lines that are connected to each other.

c) Social aspects

Curved lines and circular shapes symbolize descendants and every dayak chief in Kalimantan. The curved shape and inner circle of ornament are used as symbols of unity among Dayak people.

In ornamentation it is used as a reminder that unity among the Dayak people is important, especially when there are increasing numbers of migrant tribes and the influences they carry, as a reminder that they must also be able to maintain their traditions and characteristics amidst many external influences.

Character of Kawit Carving :

1. The basic form of kawit carving is a representation of ferns in Kalimantan, with symmetrical patterns that symbolize justice.

2. Has the meaning of a close relationship between Dayak tribes in Kalimantan and explains the unbroken descendants.

3. The form of the circle explains that the relationship between the Dayak chiefs is in Kalimantan which is united and related to each other so this also explains the meaning of unity.

4. In kawit carving using basic colors obtained from nature that have the meaning namely Bahenda: yellow, bahandang which is red, green, green, baputi or white and babilem or black.

5. Carving serves as an ornament used in buildings, musical instruments, boats, to equipment for hunting or fighting such as mandau and shields.

\subsection{Transformation of Kawit Carving}

To maintain the values of local culture on the object of this design must be determined a concept that can accommodate local values with modern so that it becomes an attraction for a library and regional icons. From this goal a concept is defined which is the identity that is present. This concept is an embodiment of regional identity that is adapted to the current situation, or renewed through a transformation process without reducing the values or meanings contained therein. This concept can be achieved through the process of transforming forms, using materials, to modern structures. the transformation process used in this design uses the geometry transformation method, Ching, 1996.

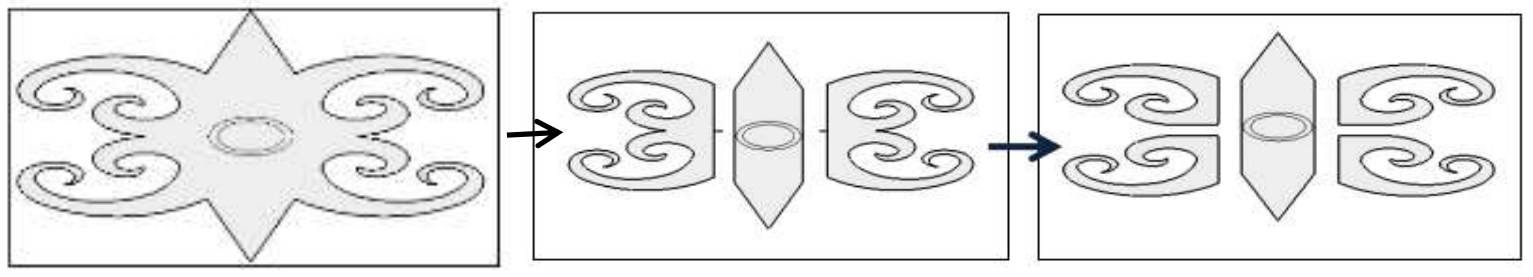

Fig.2 The concept of building shape ideas

The part of the picture above undergoes prores of change by extending to the engraving section, then the part is broken down and moved so that it becomes like the image below. From the changes in Figure 2 a reduction is made and broken down in the form of carvings, then in the middle part of the circular carving changes the scale to be bigger in figure 3 and 4 . This section will be the center of the building's shape which is a result of transformation with a symmetrical shape. 


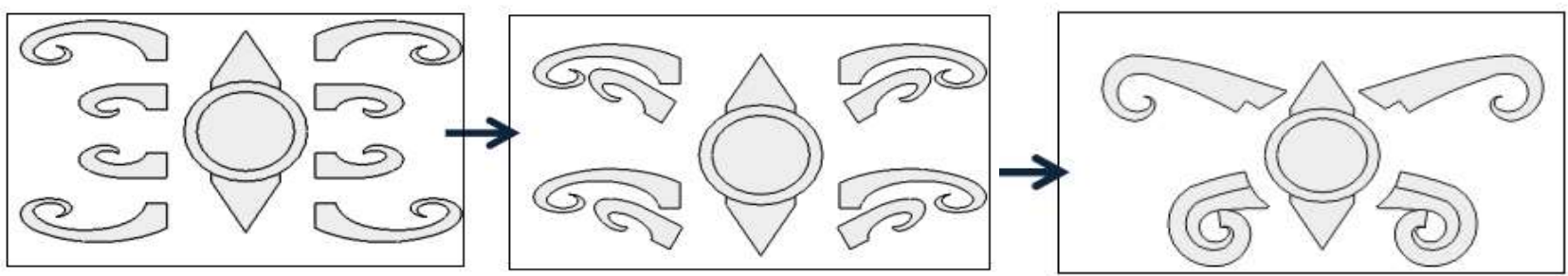

Fig.3 The shape of the enlarged circle is then moved the sides

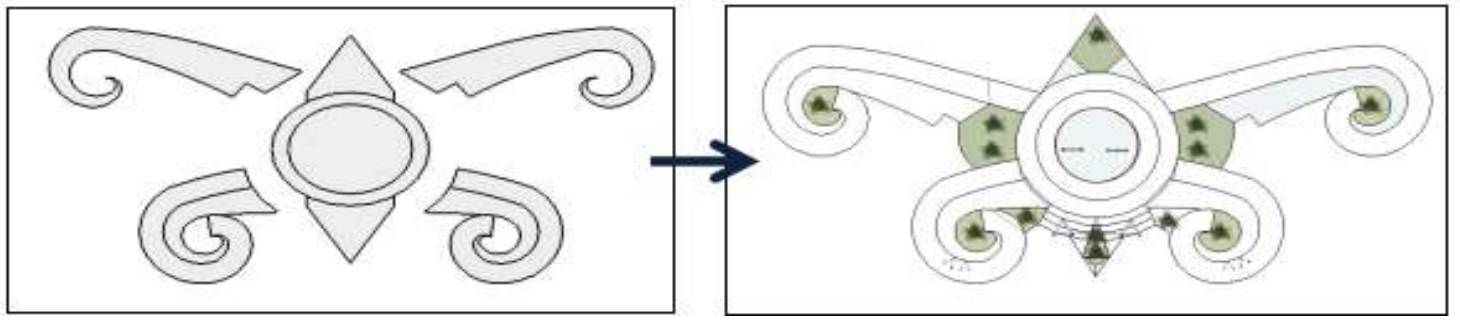

Fig.4 The process of combining the form and surrounding environment

\subsection{Regional Library}

The Regional Library is a library located in the provincial capital which is given the task of collecting, storing, preserving and utilizing all printed works and recorded works produced in the area, Basuki, 1991. This design thesis chooses the North Kalimantan regional library to be the object of design, it aims to answer the issue of increasing the reading interest of the people of North Kalimantan, especially among SCA (State Civil Apparatus). The design of this library object is a plan of the local government to be built in the city of Tanjung Selor, Bulungan Regency, North Kalimantan so that it can become an icon of the city as the Provincial Capital and is expected to be a representation of the area where the library was built.

\subsection{Aspects of Identity}

In his writing on "National Identity and Regional Identity as the Unity of the Nation", Sri Haratai explained the nation's national identity is a feature possessed by a baggage that philosophically distinguishes the nation from other nations. Based on this understanding, every nation in this world will have its own identity according to the uniqueness of the nature, characteristics and character of the nation. Based on the nature of the understanding of the nation's National Identity as explained above, the national identity of a nation cannot be separated from the identity of a nation or more popularly called the personality of a nation or can be interpreted as a large group of people who have the same fate in the historical process.

So that it has the same character and strong character to unite and live together and inhabit a certain area as a National provision. So National Identity and regional identity as a unifying nation is a unit that is bound to the region / region and always has an area / area (their own abundant land), similarities in history, culture, legal system or legislation, rights and obligations and division of labor based on profession.

Based on the book written by Bangladesh University of Engineering and Technology and Institute of Architecture, 1985. Explaining the definition of identity are general forms accepted by society into traditional forms, and when boundaries are reinforced by collectively generated values this is the character of an area. Views that are similar can be identified and differentiated simultaneously. When these forms are transformed beyond physical form, these forms become symbols with specific meanings. These symbols then become aspects of forming identity in the community or each individual. Each settlement, its structure, typology, until the forms that are built will produce the same language to become an identity. These shapes and symbols can vary in each region, depending on the equation produced, the climate of the place, and the area. The source of the form and determinant element has an important role in determining the code for an identity.

Tabel 2. Forming Aspects of Identity

\begin{tabular}{|l|c|l|}
\hline No. & Aspects of Identity & \multicolumn{1}{c|}{ Identity Study } \\
\hline 1. & Symbol & $\begin{array}{l}\text { Identity can be generated from traditional symbols that explain the meaning or history of an } \\
\text { area so that it indirectly interprets the identity of the area. These symbols can be placed on the } \\
\text { wall as ornaments, on fences, frames or on the roof of the house. Each symbol also has its own } \\
\text { meaning and function. }\end{array}$ \\
\hline
\end{tabular}




\begin{tabular}{|l|l|l|}
\hline 2. & Traditional form & $\begin{array}{l}\text { Design by taking forms from traditional buildings which are the inheritance of the area, so that } \\
\text { this becomes a representation of buildings that have a response to place and time. }\end{array}$ \\
\hline 3. & Response to climate & $\begin{array}{l}\text { Having a response to climate, because climate is one of the determining factors that } \\
\text { distinguishes one region from another, so that the design results will be different in each region } \\
\text { that has a different climate. This is achieved through thick walls to isolate cold and humid air } \\
\text { in the room, with wide overhangs and small ventilation to overcome the hot and dry climate in } \\
\text { West India. }\end{array}$ \\
\hline 4. & $\begin{array}{l}\text { Presents identity from pre-existing form typologies. This can be achieved through the details of } \\
\text { the components in the building, the typology of forms, spaces, structures that are considered to } \\
\text { be able to solve the problems in social relations of each community. The example is explained } \\
\text { in the design of the city of Jaisalmer on a macro basis, about the city order, the transition from } \\
\text { the public zone to the private zone, to the circulation area which is regulated based on mutual } \\
\text { interests in resolving any problems in that area. }\end{array}$ \\
\hline 5. & $\begin{array}{l}\text { Using local materials such as red bricks, wood and other local materials that exist in an area } \\
\text { that aims for independence, saving energy, and low production and transportation costs. }\end{array}$ \\
\hline
\end{tabular}

\section{CHARACTER of KAWIT CARVING in LIBRARY}

In this process the application of the kawit carving symbol is used in the shape of the building with changes to its scale, then the direction on the part of the arch that changes its position so that it becomes parallel to one direction.

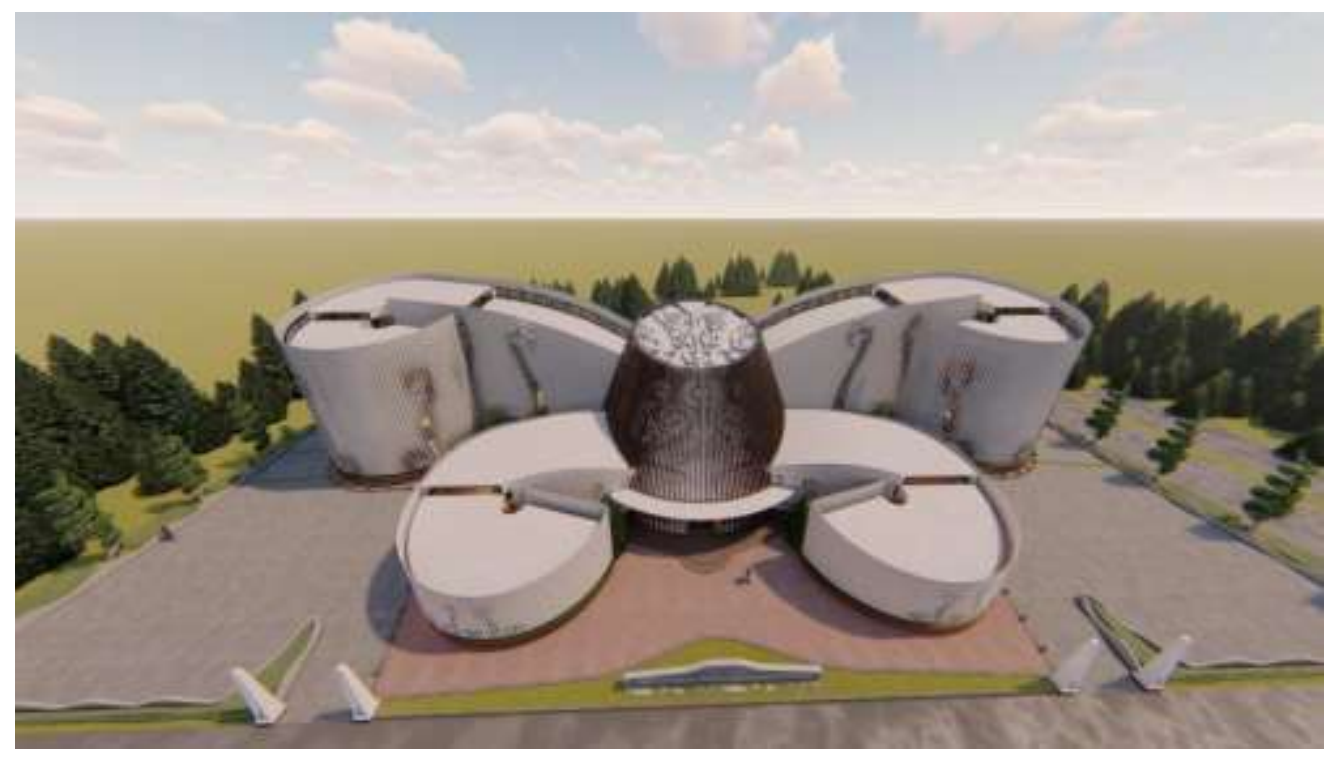

Fig.5 Implementation of curved shapes from kawit carvings on buildings

In building facades the transformation of kawit carving is done by punching holes in the facade with a square pattern to form carvings with different hole sizes so as to produce gradations between transparent parts and solid parts. The results of this transformation make kawit carvings on the facade can only be seen from a certain distance, or from distances outside the site because the scale of the carvings and square patterns are large enough to adjust to the scale of the building. 

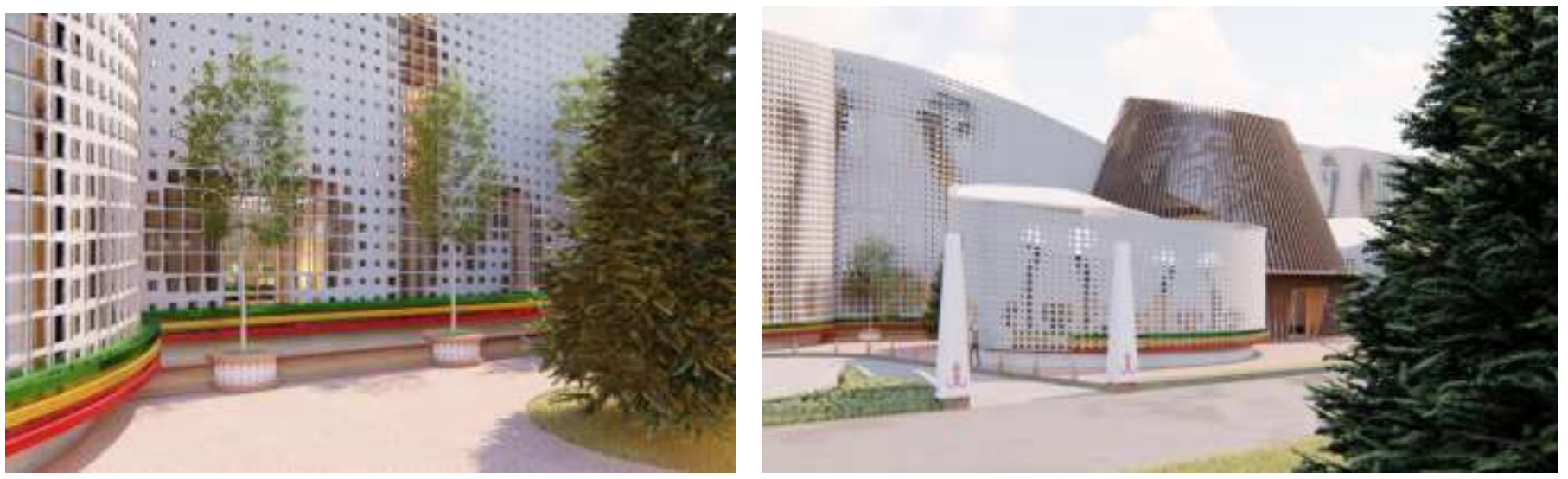

Fig.6 Square pattern on facade which forms a kawit carving pattern

In the inside of the building the use of the kawit carving symbol in the form of a shadow forming an ornament is located in the center of the building which is used as a transition area for public zones and private zones, besides this area is a service area and vertical circulation in buildings where the center is used for elevators and bathroom / wc. In spaces that function as collection rooms and reading rooms and spaces with other public zones kawit carving symbols are placed on the sides of the building, and on structural elements such as columns, this is an implementation of the placement of kawit carvings on the Lamin traditional house.
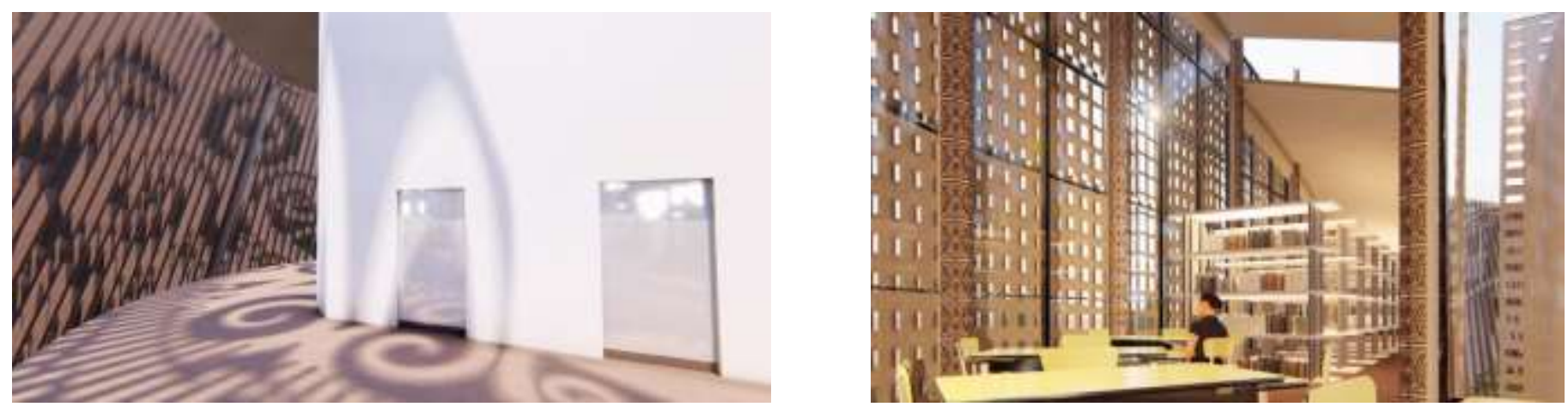

Fig.7 Kawit carving pattern in the inner space

The pattern in the outer space follows the shape of the building, while the elements of the outer space are part of the kawit carving that has been transformed by maintaining the curved shape of the kawit carving which is the identity of this design. The shape of this arch is applied to the rear garden which is used as a plaza and the barrier between the parking lot and the park. The fence is made with endless curvilinear patterns that explain the meaning of kawit carving as a symbol of unity between the endless descendants of the Dayak tribe.
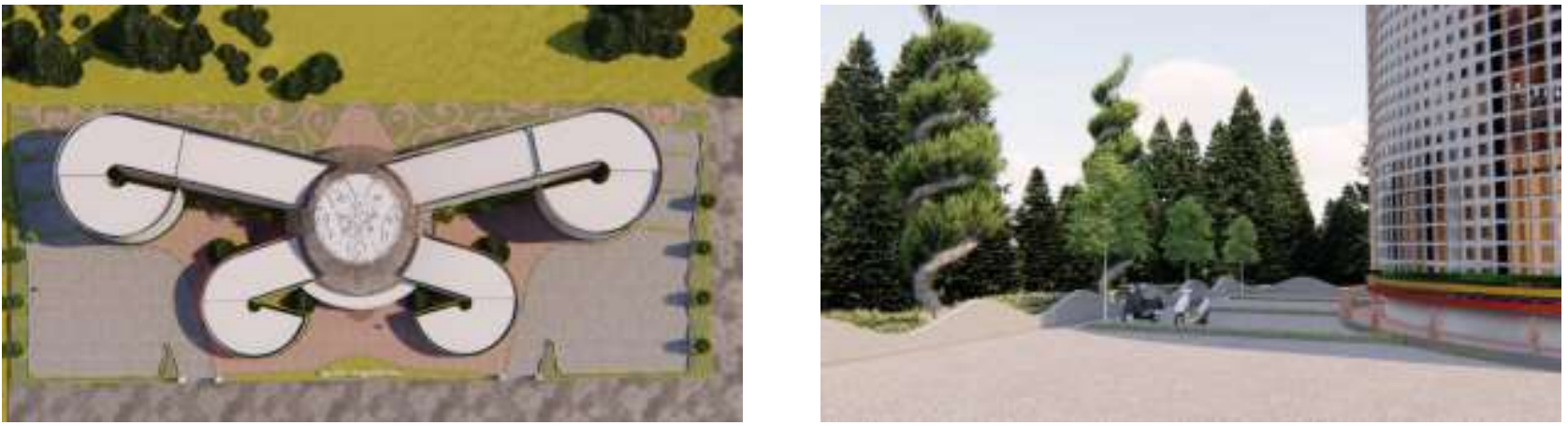

Fig.8 Kawit carving patterns on the site

\section{CONCLUSION}

The forms of kawit carvings that have been transformed are implemented in buildings through building forms, floor plans and circulation, facades and outer space. In addition, it explains about space zones in buildings that are divided into public zones for visitors and private zones for managers. 
In realizing this carving as an identity in the library, there are several parts of the building that can show the identity of kawit carvings, including buildings that maintain the curved shape of kawit carvings, with some changes but do not eliminate their identity. This explains the aspect of the symbol as the identity shown by the kawit carving on the design of the North Kalimantan regional library building.

\section{ACKNOWLEDMENT}

I would like to express my special thanks to the village head of Malinau, and to the North Kalimantan Regional Archives and Library Office for their assistance in my research.

\section{REFERENCES}

1. Billa, M. “Kekayaan dan Kearifan Budaya Dayak,” Mumtaz Sumber Sejahtera, Jakarta, 2017.

2. Ching, Francis D.K. “Architecture : Form, Space, and Order," John Wiley and Sons, London, $2^{\text {nd }}$ Edition, 1996.

3. Basuki. "Pengantar Ilmu Perpustakaan," Gramedia Pustaka Utama, Jakarta, 1991.

4. S. Hartati, Identitas Nasional Dan Identitas Daerah Sebagai Persatuan Bangsa. Unpublished.

5. Bangladesh University of Engineering and Technology and Institute of Architecture., Regionalism in Architecture, Concept Media Pte Ltd, Singapore, 1985.

\section{AUTHORS}

First Author - Evan Christian, Postgraduate Student of Architecture Design, Department of Architecture, Institute Technology Sepuluh November,

Second Author -Murni Rachmawati, Senior Lecturer of Theory and Architectural Criticism, Institute Technology Sepuluh November.

Third Author - Bambang Soemardiono, Associate Professor in Urban landscape Department of Architecture, Institute Technology Sepuluh Nopember . bamsoem03@yahoo.com 